\title{
Article \\ Cynical or Deliberative? An Analysis of the European Commission's Public Communication on Its Use of Expertise in Policy-Making
}

\author{
Cathrine Holst * and John R. Moodie \\ ARENA-Centre for European Studies, University of Oslo, 0855 Oslo, Norway; E-Mails: cathrine.holst@arena.uio.no (C.H.), \\ j.r.moodie@arena.uio.no (J.R.M.) \\ * Corresponding author
}

Submitted: 5 February 2015 | In Revised Form: 19 March 2015 | Accepted: 25 March 2015 | Published: 31 March 2015

\begin{abstract}
The European Commission has faced increasing criticism that its use of expertise in policy-making is undemocratic and politicized. In response to critics, the Commission has produced a number of publicly available documents where its expert policies and practices are outlined and discussed. Cynics view public communications of this nature with skepticism, as organizations tend to adopt "smooth talk" and cosmetic rhetoric designed to placate critics and create a façade of compliance aimed at decreasing external pressure. An alternative deliberative approach, would expect the Commission to engage in a relatively open, reflective and reason-based interchange. The article's main aim is to assess the relative merits of these two approaches in capturing the Commission's framing of its public communication. Cynical expectations, prevalent among Commission critics, are confirmed by the Commission's silence on unpleasant topics including the undemocratic nature of existing expertise arrangements and the strategic uses of knowledge in EU policy-making. However, firm regulatory initiatives and the Commission's critical engagement with democratization demands and possible goal conflicts within their critics' agenda give significant leverage to a deliberative approach.
\end{abstract}

\section{Keywords}

deliberative democracy; European Commission; expertise; knowledge utilization; organized hypocracy; public communication

\section{Issue}

This article is part of the special issue "The Role of Expert Knowledge in EU Executive Institutions", edited by Professor Åse Gornitzka (University of Oslo, Norway) and Dr. Cathrine Holst (University of Oslo, Norway).

(C) 2015 by the authors; licensee Cogitatio (Lisbon, Portugal). This article is licensed under a Creative Commons Attribution 4.0 International License (CC BY).

\section{Introduction}

The European Union's (EU) main executive body, the European Commission, routinely consults experts, and is reliant on knowledge as its main source of legitimacy (Boswell, 2008a; Dehousse, 2011; Ross, 1995). The increasing role of experts challenges established ideas of accountability and democratic decision-making and has spurred tension at the supranational level, contributing to the democratic deficit debate and the technocratic image of the EU (Featherstone, 1994; Radaelli, 1999). The most recent manifestation of this criticism came in October 2014 when the European Parliament placed a moratorium on funding for Commission expert groups, accusing them of being closed, dominated by vested corporate interests and lacking transparency (Alter-EU, 2014). As a result, the Commission has faced growing external pressure to change its expert advice approach and arrangements.

In response to critics, the Commission has published a number of publicly available documents examining the role and use of knowledge and expertise in EU policy-making. What can we expect from these documents? Which positions and perspectives will most likely prevail? The article addresses this question by contrasting two competing theoretical approaches. 
A branch of organizational theory-we refer to its representatives as "the cynics" - would hypothesize that public communications of this nature are primarily cosmetic and to be viewed with skepticism as organizations will engage in symbolic rhetoric to defuse external criticism, obfuscate real motives, and defend existing internal structures. An alternative, deliberative perspective would anticipate that the Commission adopts a relatively open, reflective approach based on reason-giving. The article's main aim is to assess the relative merits of the two theoretical perspectives in capturing the Commission's framing of its public communication.

The next section introduces central features of the Commission's use of expert advice, and elaborates on recent controversies and criticisms that have been raised against the Commission's expert policies and practices. It is argued that critics attack the Commission for disregarding democratic concerns, but also for their strategic use of expertise. The following section presents the cynics' and deliberativists' competing approaches in more detail and spells out operational hypotheses. Section 4 reflects on data and methods, and is followed by section 5 which presents the analysis of the Commission's documents and main findings. It is argued that cynical expectations are confirmed by the Commission's silence on unpleasant topics. However, the introduction of regulatory initiatives and the Commission's critical engagement with democratization demands and possible goal conflicts within the critics' agenda, give significant leverage to a deliberative approach. The final section sums up the article and delineates a few implications.

\section{The Commission under Fire: Democratic Deficit and Strategic Knowledge Utilization}

Expertise is deeply entrenched within the institutional structure of the EU (Böhling, 2014; Boswell, 2008a; Egeberg, Schaefer, \& Trondal, 2003; Radaelli, 1999; Rimkute \& Haverland, 2014; Schrefler, 2010), and the European Commission, in particular, is reliant on knowledge and expert advice in lieu of a direct electoral mandate (Moodie, 2011; Trondal, 2001). In addition to its in-house expertise, the Commission now routinely consults external experts to assist in the formulation and implementation of policy (Metz, 2013; Schaefer, 2002). This recourse to expert knowledge and advice is reflected in the development of a large number of EU-level agencies, comitology committees and expert groups (Christiansen \& Kricher, 2000; Christiansen \& Larsson, 2007; Gornitzka \& Sverdrup, 2008, 2010; Joerges \& Neyer, 1997; Larsson, 2003; Pedler \& Schaefer, 1996; Stie, 2013; Vos, 1997).

The growing number of expertise-based bodies at the supranational level has served to increase academic interest in the different functions of knowledge in EU policy-making (Haas, 2004; Radaelli, 1995). Building on literature examining knowledge utilization in public policy-making (Weiss, 1979, 1986, 1999), EU scholars have developed different ingrained conceptualizations of the Commission's uses of expertise, but discussions have tended to circulate around three main functions: the instrumental, the substantiating and the symbolic (Boswell, 2008a; Radaelli, 2009; Rimkute \& Haverland, 2014; Schrefler, 2010). ${ }^{1}$

The Commission uses knowledge instrumentally when it turns to experts to provide background information, "evidence" and technical solutions to help assist in task performance, enhance understanding, increase the number of policy options available, and improve the quality of policy outputs (Boswell, 2008a; Haas, 2004; Majone, 1996; Radaelli, 2009; Rimkute \& Haverland, 2014; Scharpf, 1999; Schrefler, 2010; Weiss, 1977). The instrumental use of expertise is viewed as central for ensuring the Commission's institutional autonomy and social legitimacy: its authority rests decisively on its ability to act in a neutral manner and base policies on sound evidence, rather than on political or strategic interests (Boswell, 2008a; Majone, 1996; Rimkute \& Haverland, 2014). The instrumental function is also intimately linked to a standard approach to the normative legitimacy of expert involvement in policy-making: if expert involvement is defensible, it is defensible-or so it is often argued-on the grounds that it contributes to better and more "truth-sensitive" decisions, increases problem solving capacity and contributes to more effective policies (Christiano, 2012; see also Martí, 2006).

However, the way an organization actually uses expertise seldom fits neatly with the doctrine of instrumental knowledge utilization (Groenleer, 2009; Schrefler, 2013). Knowledge serves a substantiating function when expertise is used selectively to justify predetermined policy decisions, whereas the symbolic function of knowledge refers to institutions' use of expertise to enhance their position and power vis-à-vis other institutions and stakeholders (Haas, 2004; Herbst, 2003; Boswell, 2008; Rimkute \& Haverland, 2014; Schrefler, 2010). The latter then is more about demonstrating competence and "epistemic authority", than about enlightening the case in question or solving specific policy problems (Geuss, 2001; Rimkute \& Haverland, 2014).

These non-instrumental political or strategic uses of expertise $^{2}$ are less official. Most bureaucrats, including Commission officials, are, however, likely to be well

\footnotetext{
${ }^{1}$ What Schrefler (2010) identifies as the "symbolic" function of knowledge is referred to by Boswell (2008) and Rimkute and Haverland (2014) as the "legitimizing" function. Radaelli (2009) and Schrefler (2010) also refer to the "political strategic" use of knowledge; however, as Rimkute and Haverland (2014) point out, this use is closely interlinked with the symbolic function.

2 In this article we will use the terms "strategic", "political", "politicized" and "non-instrumental" interchangeably when referring these utilizations of expertise.
} 
acquainted with them (Aberbach, Putnam, \& Rockman, 1981; Boswell, 2008; Ellinas \& Suleiman, 2012). The political functions of knowledge in EU policy-making have also been given substantive attention in research, where some contributors have presented the Commission as a power-hungry organization that is adept at utilizing expertise strategically in order to enhance its policy preferences and competences (Green-Cowles, 1995; Eising, 2007; Sandholtz \& Zysman, 1989).

Criticism of the Commission's political, noninstrumental uses of expertise has been raised outside academia as well. The role of knowledge and experts in EU policy-making has for a long time been a highly contested topic. In the early 1990s, a number of public controversies surrounding new risks and transformative technologies (genetically modified crops, biofuels, mad cow disease, stem cells, etc.) contributed to increased public skepticism towards the scientific establishment and the EU's expertise reliance (Fischer, 2008). The resignation of the Santer Commission in 1999 over allegations of corruption and nepotism further undermined public confidence in the Commission and gave fuel to the Eurosceptic critique that Europe is dominated by an unelected and unaccountable technocratic elite (Featherstone, 1994; Harcourt \& Radaelli, 1999; Presson, 2007; Rhinard, 2002; Wallace \& Smith, 1995). The 2008 financial crisis has once more served to enhance the Commission's technocratic image, as the Troika has become a symbol of the "façade democracy" or "post-democratic executive federalism" that is developing in the Union, according to critics (Habermas, 2012; Majone, 2014; Offe, 2014). More concretely, the European Commission expert group system has been criticized for being closed and dominated by vested corporate interests. This led the European Parliament, in October 2014 (and previously in November 2011 and March 2012), to place a moratorium on expert group funding until the Commission met demands to balance the composition of expert groups, develop an open calls system for the recruitment of members, and introduce fuller transparency measures (Alter-EU, 2013, 2014).

Critics of the Commission have coalesced around demands for greater "democracy" and "democratization" of expertise as an antidote to the increased leverage of experts and technocrats (Gornitzka \& Sverdrup, 2008; Metz, 2013). However, critics are equally worried about political knowledge utilization and the Commission becoming what one critic, MEP Ingeborg Grassle, has described as a "self-serving bureaucracy" (cited in Dehousse \& Thompson, 2013). A recurrent accusation is that the Commission utilizes expertise strategically to pursue predetermined policy goals and increase its own power. The problem is not only a lack of respect for "democracy", but also politicized modes of knowledge utilization that compromise instrumental knowledge utilization and the quality of policy outputs. As Alter-EU representative Yiorgos Vas- salos (2013) notes: "when the expertise, on which a policy or legislation is based, is biased, the possibilities of getting a bad policy result increase-namely a policy that serves the interests of those capturing the advice rather than the general interest."

\section{Analyzing the Commission's Public Communication: A Cynical Versus a Deliberative Approach}

Critics' suspicions that the Commission is engaged in political knowledge utilization seem to reflect a more deep-seated skepticism towards the Commission's initiatives and responses. Accordingly, when the Commission has replied to criticism of its use of and approach to expertise, critics typically read this communication flow as cosmetic and failing to engage substantially with the concerns raised: "The Commission gives the impression that it is rather looking for alternative ways to keep up its privileged relationship with corporate interests than looking to express the majority of citizens" (Vassalos, 2013). The Commission is "found wanting", and accused of "broken promises" behind a façade of "commitment to reform": "Commission commitments currently (are) just hot air" (Alter-EU, 2013).

Is this rather cynical reading of the Commission's response to the criticism of its expert policies and practices fair? We will investigate this question on the basis of an organizational theory approach which links closely with this cynical perspective. These are theories of organizational behavior claiming that any organization's main aim is to survive and enhance its autonomy and authority (DiMaggio \& Powell, 1983; Meyer \& Scott, 1983; Scott, 2004). The typical strategy in situations of external pressure is then to adopt "smooth talk" and cosmetic rhetoric to placate critics and create a façade of compliance with their demands without seriously undermining the coherence of the organization's internal structures and priorities (DiMaggio \& Powell, 1983). Meyer and Rowan (1977) refer to this as "institutional decoupling"; Nils Brunsson (2002) talks about "organized hypocrisy". Central to these theories are the various mediums through which an organization can interact "hypocritically" with their external environment, including official documents. From a cynical perspective, there is thus need to approach such documents with caution and skepticism, and as for organizations' public communication under pressure, the prediction would be little, substantial engagement with critics' concerns and demands. Genuine deliberations are perceived to take place in "private" or "back stage" settings only, whereas public "front stage" communication is imagined more as a public relations exercise.

Even cynics, however, would have to differentiate between different organizations and how their core norms and activities will vary according to their structure, demography, locus and level of institutionalization (Egeberg, 2004, pp. 201-205). Organizational theo- 
ry argues that the relative strength of an organization's internal culture and norms will determine the nature of its response to external criticism (Boswell, 2008b; Meyer \& Scott, 1983; Scott, 2004). In the case of the Commission, analyses tends to emphasize how it has developed "its own ethos and a strong esprit de corps", having become "'the House', as it is referred to colloquially and affectionately by its staff" (Egeberg, 2004, p. 214; see also Dehousse, 2011, Egeberg et al., 2003, Ross, 1995, Shore, 2000, p. 127, Trondal, 2001). Such high levels of organizational identification would suggest a strong inclination among Commission officials to protect the "House" ethos when faced with external criticism. Hence, if there is something to cynics' expectations of hypocritical decoupling within an organization, then the Commission would seem a most likely case.

Specific cynical hypotheses $(\mathrm{CH})$ about the Commission's public communications on its use of expertise follow from this perspective concerning the approach to 1) critics' positions, 2) inconsistencies in critics' arguments and 3) unpleasant topics for the Commission. With regard to 1 , we could expect the Commission to agree with critics' views to reduce external pressures, and so subscribe to the virtues of the official doctrine of instrumental knowledge utilization ( $\mathrm{CH} 1 \mathrm{a})$, support demands to democratize Commission policy-making and expertise arrangements ( $\mathrm{CH} 1 \mathrm{~b})$, while denouncing strategic uses of knowledge ( $\mathrm{CH} 1 \mathrm{c})$. With regard to 2, we could for similar reasons anticipate little or no focus on revealing the possible goal conflict between instrumental knowledge utilization and critics' democratization demands ( $\mathrm{CH} 2 \mathrm{a}$ ). Finally, with regard to 3, the expectation would be little or no acknowledgment of undemocratic features of current Commission arrangements ( $\mathrm{CH} 3 \mathrm{a})$, and no mentioning of the politicized knowledge utilization practices within the Commission's own ranks (CH3a) in order to avoid more critical exposure.

We will contrast the cynical approach and the above hypotheses with an alternative deliberative approach with competing expectations as to the Commission's communications on its expert policies and practices. Political philosopher Joshua Cohen (1997, p. 72) describes deliberative democracy and politics as being characterized by a "commitment" among participants "to the resolution of problem and collective choice through public reasoning" (see also Bohman \& Rehg, 1997; Chambers, 2003; Gutmann \& Thompson, 2004; Besson \& Marti, 2006; Mansbridge \& Parkinson, 2012). One could argue that a legitimate rule should be "deliberative", while at the same time denying that deliberation characterizes politics as it is currently practiced. However, deliberative theorists typically expect that deliberation takes place: "Rational choice" and "strategic calculations of mutual advantage" are central to political processes and discussion, but "reason-giving" is a primary coordinating mechanism (Eriksen, 2014, pp. 14, 26; see also Eriksen, 2009).
The deliberative approach also generally anticipates a positive relationship between publicity and the quality of deliberation as "the absence of publicity often limits deliberative capacity" (Mansbridge \& Parkinson, 2012, p. 11; see also Chambers, 2004, p. 389). Mansbridge \& Parkinson (2012) note that since topics of deliberations are "issues of common concern...epistemically wellgrounded preferences, opinions, and decisions must be informed by, and take into consideration, the preferences and opinions of fellow citizens". This gives a different set of expectations to communication in public, front-stage settings: Where cynics would expect deliberations on the use and role of expertise by the Commission to take place primarily back stage, deliberativists will anticipate deliberation and reasoning in the Commission's public communications. ${ }^{3}$

Moreover, some deliberativists would anticipate greater deliberation within an EU context than at the national level (Eriksen, 2014; see also Joerges, 2001) because the EU is a "government without a state" (Eriksen \& Fossum, 2012) and thus lacks the conventional coercive means of states. According to this reading of the EU project, EU integration, policy and decision-making is "non-coercive" and characterized by "learning and pragmatic problem-solving": "when the instruments of power are lacking, actors have to sort out their differences through argumentation in order to find a solution to a common problem" (Eriksen, 2014, p. 33). If so, the Commission is once more a most likely case: If a fit with the deliberative approach is to be found anywhere, it must be in the Commission's communications, considering this organization's role as pursuer of EU integration.

Specific deliberative hypotheses (DH) regarding the Commission's public communication on its use of expertise can be deduced from this branch of theory and contrasted with the cynical hypotheses outlined above. Concerning the approach to its critics' positions, we could expect the Commission to agree or disagree with their views on instrumental knowledge utilization (DH1a), democratization (DH1b) and strategic uses of expertise (DH1c), depending on what it finds reasonable. As for inconsistencies in critics' arguments, the general expectation would be that the Commission addresses them if it finds good reasons to do so, including the possible goal conflict between instrumental knowledge utilization and critics' democratization de-

\footnotetext{
${ }^{3}$ A key discussion in contemporary deliberative theory concerns the more exact scope conditions for the positive relationship between publicity and deliberative quality (see Chambers, 2004; Thompson, 2008). The ambition here is, however, to give a coherent presentation of a theoretical account with competing expectations to public communication relative to those of the cynical approach. Just like organizational theory, deliberative theory is a broad scholarly tradition, but a more detailed presentation and assessment falls beyond the scope of this article.
} 
mands ( $\mathrm{DH} 2 \mathrm{a}$ ). Finally, with regard to unpleasant topics for the Commission, we could anticipate potentially undemocratic features of current Commission arrangements (DH3a), as well as any politicized knowledge utilization practices (DH3b), to be recognized and openly discussed (see Table 1).

\section{Data and Methodological Reflections}

To test these hypotheses we have analyzed publicly available Commission documents. The documents that form the basis of our analysis include working documents, white papers, reports, action plans, framework papers, communications, and regulatory documents on principles and guidelines for the use and organization of expertise (European Commission, 2000, 2001a, 2001b, 2002a, 2002b, 2005, 2007, 2010a, 2010b, 2012, 2013). The final selection is the result of a wide search for documents that deal with the use and role of expertise in EU policy-making, and several of them are framed specifically as a direct response to the problems and criticisms raised by external actors. Most of the documents approach the topic generally, discussing "knowledge and society", "democratizing expertise", etc. as broader topics, while others discuss concrete expertise arrangements and expert advice procedures. As the Commission's system of expert groups have been a main target of critics, we have traced documents on this system in particular.

The documents cover the time period from 2000 to 2013. They reflect, therefore, an ongoing discussion over a 13 year period, and not merely a snapshot of the Commission's position at a certain moment in time. The selected documents are all within the range of what we could meaningfully refer to as this executive organization's "public communication". They are fully available in the public realm to all those who wish to consult them, and due to the heated debates on the Commission's use of expertise we could expect them to be scrutinized by a range of actors. The Commission may of course hold "private" views that are not covered by the documents. The documents are, finally, what the Commission communicates on its expertise policies and practices. This does not necessarily reflect what it does in practice.

In our analysis of these documents, we have systematically coded passages to assess the relative merits of the cynical and deliberative hypotheses. The method applied is qualitative content analysis. ${ }^{4}$ In accordance with this approach, the hypotheses are in part deduced from theory, and in part the result of data familiarization. $\mathrm{CH} / \mathrm{DH} 2 \mathrm{a}$ can serve as an example. Silence/deliberation on potential conflicts within the critics' agenda is a theoretically deduced indicator, while the fully-fledged operational hypothesis on the instrumental knowledge utilization/democratization conflict is the product of a hermeneutical back and forth process between theory and documentary reading. To increase coding reliability, both authors have searched and coded the documents. Coded passages with multiple possible meanings have been highlighted and taken up for explicit discussion among the authors in the assessment process.

\footnotetext{
${ }^{4}$ See Mayring (2000), but also Hsieh and Shannon (2005) on
} "the directed approach".

Table 1. List of hypotheses about the European Commission's public communication on its use of expertise

$\begin{array}{ll}\begin{array}{l}\text { Cynical hypotheses }(\mathrm{CH}) \text { on Commission } \\ \text { communication }\end{array} & \begin{array}{l}\text { Deliberative hypotheses (DH) on Commission } \\ \text { communication }\end{array}\end{array}$

$\mathrm{CH} 1 \mathrm{a}$ Agreement with critics' support of instrumental knowledge utilization

CH1b Agreement with critics' demands for democratization

$\mathrm{CH} 1 \mathrm{c}$ Agreement with critics' dismissal of politicized knowledge utilization

$\mathrm{CH} 2 \mathrm{a}$ Silence on instrumental knowledge utilization/democratization conflict

$\mathrm{CH} 3 \mathrm{a}$ Silence on undemocratic features of the Commission's ongoing expertise practices

$\mathrm{CH} 3 \mathrm{~b}$ Silence on the strategic uses of knowledge within the Commission's own ranks
DH1a Agreement or disagreement with critics' support of instrumental knowledge utilization

DH1b Agreement or disagreement with critics' demands for democratization

DH1c Agreement or disagreement with critics' dismissal of politicized knowledge utilization

$\mathrm{DH} 2 \mathrm{a}$ Deliberation on instrumental knowledge utilization/democratization conflict

DH3a Deliberation on undemocratic features of the Commission's ongoing expertise practices

$\mathrm{DH} 3 \mathrm{~b}$ Deliberation on the strategic uses of knowledge within the Commission's own ranks 


\section{Findings and Discussion}

\section{1. $\mathrm{CH} / \mathrm{DH} 1 \mathrm{a}$ and $\mathrm{CH} / \mathrm{DH} 1 \mathrm{c}$ : The Commission Subscribes To Instrumental Knowledge Utilization and Denounces Non-Instrumental Political Uses of Expertise}

The official function of expertise in policy-making is the instrumental, and it is perhaps not surprising that the Commission, just as their critics, subscribe without much ambivalence to the idea that expert bodies and expert advice should contribute to problem-solving and enlightenment. The Commission strives to make their activities and policies "knowledge-based": "(...) it is crucial that policy choices are based and updated on the best available knowledge", and "the right expertise at the right time" (European Commission, 2002a), to ensure "better quality decision-making" (European Commission, 2001b). Like its critics, the Commission also expresses concern about the strategic, politicized use of expertise. It recognizes firmly the "risk" of partial and selective knowledge utilization and of "policymakers just listening to one side of the argument or of particular groups getting privileged access" (European Commission, 2002b).

These findings are equally compatible with a cynical and a deliberative approach. The Commission's positions can be built on reason-based conviction, but can also reflect an opportunistic, superficial adaption to critics' agenda with the aim of easing external pressure. Abstract, evaluative passages where the Commission states its support for "the best available knowledge", for "quality" of "expertise", "scientific expertise", "policies" and "decisions", and for "impartiality" and "neutrality" in expert selection and knowledgeproduction, easily lend themselves to cynical interpretations: These are low risk statements acknowledging "everyone's" concern. ${ }^{5}$

However, the definite regulatory character of some of the documents, gives leverage to a deliberative interpretation. In these documents, general talk of "quality", "transparency" and "accountability" of expertise is operationalized and made concrete via specific rules and regulations. The Commission promises to "publish guidelines on collection and use of expert advice so that it is clear what advice is given, where it is coming from, how it used and what alternative views are available" (European Commission, 2001a), adding to already existing measures-consensus conferences, citizens' juries and science shops-put in place to ensure more "impartial" and "democratized" expertise and expertise consultation processes (European Commission, 2000a, 2001b, 2002a). The Commission goes on to introduce a number of minimum requirements in relation to expert group composition: "When defining

${ }^{5}$ See also Gallie (1956) on "essentially contested concepts". the composition of expert groups, the Commission and its departments shall aim at ensuring a balanced representation of relevant areas of expertise and areas of interest, as well as a balanced representation of gender and geographical location" (European Commission, 2005). More specifically, "where the Commission or its departments appoint the members of the expert groups, they shall seek a balance between men and women; the medium term aim shall be to have at least $40 \%$ of representatives of each gender in each expert group" (European Commission, 2005). And finally, "(w)hen creating the expert group, the DG concerned shall describe the composition of the group in general, indicating categories of experts forming part of it: national, regional or local public authority represented, civil society organization represented, interested parties, scientific or academic experts" (European Commission, 2005). ${ }^{6}$

Critics may, of course, disagree with some of these guidelines, consider them too weak or unambitious to protect the quality of expert advice from politicization and strategic use, or question the extent to which the Commission implements them effectively, or even intends to implement them effectively. However, these minimum requirements exist and provide a benchmark on which the Commission can be judged. They might not fully satisfy critics, but their existence creates a restrictive barrier against the non-instrumental uses of expertise making the development of "imbalanced" groups, consisting exclusively, or predominantly, of experts supporting the Commission's predetermined policy positions more complicated. In this regard, a cynical reading of the Commission's public communication on expertise has limited applicability.

\section{2. $\mathrm{CH} / \mathrm{DH} 1 \mathrm{~b}$ and $\mathrm{CH} / \mathrm{DH} 2 \mathrm{a}$ : The Commission Challenges Critics' Demands for Democratization and Addresses Potential Conflicts between Instrumental Knowledge Utilization and the Democratization of Expertise}

The Commission highlights its support for "democracy" and "democratizing expertise"; "(...) it (the Commission) wishes to stress that it will maintain an inclusive approach" to expert advice, "in line with the principle of open governance: Every individual citizen, enterprise or association will continue to be able to provide the Commission with input" (European Commission, 2002b), and "all relevant interests in society should have the opportunity to express their views" (European Commission, 2002b). Once more, such general state-

\footnotetext{
${ }^{6}$ In addition to these regulatory minimum requirements, the Commission outlines, within Status Reports, compositional changes to expert groups specifically identified by the European Parliament and pressure groups as being unbalanced (European Commission, 2012, 2013).
} 
ments fit well with a cynical reading of public documents. Statements of this nature may be based on conviction; they do not falsify deliberative expectations, but give deliberativists little to work with.

The Commission's overall message with regard to the democratization is, however, more complex. There are, firstly, the proposed regulations and reforms of the Commission's expertise arrangements with the aim of "democratizing" expertise as well as increasing "quality" and "impartiality": The introduction of binding requirements on gender balance, national composition, civil society participation, etc., decreases the impression of superficial responsiveness (European Commission, 2005; see also previous subsection).

Secondly, in these Commission documents, there is an ongoing explicit engagement with the relationship between instrumental knowledge utilization and participatory ideals. The Commission notes that expertise reliance and expert advice, if framed and institutionalized adequately, can go hand in hand with a democratization of knowledge utilization: “(...) by fulfilling its duty to consult, the Commission ensures that its proposals are technically viable, practically workable and based on a bottom-up approach. In other words, good consultation serves a dual purpose by helping improve the quality of the policy outcome and at the same time enhancing the involvement of interested parties and the public at large" (European Commission, 2002a).

Stress is here put on what is regarded as a positive relationship between greater epistemic diversity-or "knowledge plurality" - and high quality of policy outputs: "The final determinant of quality is pluralism. Wherever possible, a diversity of viewpoints should be assembled. This diversity may result from differences in scientific approach, different types of expertise, different institutional affiliations, or contrasting opinions over fundamental assumptions underlying the issue" (European Commission, 2002a). A central indicator of "plurality" is that expertise extends beyond scientific knowledge, including also practical and ethical knowledge. This will contribute to high quality decisions that are sufficiently "socially robust" (") $\mathrm{t}$ )he objective is to deliver knowledge for decision-making that is socially robust"): "This implies a notion of expertise that embraces diverse forms of knowledge (plurality). Expertise should be multi-disciplinary, multi-sectoral and (...) include input from academic experts, stakeholders, and civil society", as well as from individual citizens ("ordinary members of the public, once they have all the information in their possession") (European Commission, 2000a), and expertise review that goes "beyond the traditional peer community, including, for example, scrutiny by those possessing local or practical knowledge, or those with an understanding of ethical aspects" (European Commission, 2001b).

The next step of the argument is to link this idea of "socially robust" high quality decisions through the promotion of epistemic diversity to a democratic lexicon relating to "democratization", "participation", "involvement", "transparency", "accountability" and "bottom-up" control: "(T)he quality of EU policy depends on ensuring wide spread participation throughout the policy chain" (European Commission, 2001a), and "involvement of interested parties through a transparent consultation process, which will enhance the Commission's accountability" (European Commission, 2002b). The Commission wants to ensure that "its proposals are technically viable, practically workable and based on a bottom-up approach. In other words, good consultation serves a dual purpose by helping improve the quality of the policy outcome and at the same time enhancing the involvement of interested parties and the public at large" (European Commission, 2002a). In short: in the Commission's communications, expertisebased policy-making and enhanced democracy are simultaneously possible and desirable.

One may agree or disagree with the Commission's views, but its position has seemingly come about after some argumentative work reflected in many of the documents; in particular, in the "Taking European Knowledge Society Seriously" expert group report (European Commission, 2007), which discusses recent academic research on the epistemic merits of cognitive pluralism. Cynics could, however, question the depth and sincerity of these deliberations ${ }^{7}$, and take them to be a somewhat more sophisticated variant of low risk "smooth talk" framed to make critics satisfied.

However, parallel to the harmonizing picture outlined above, runs a story of how "democratization" and "participation", if taken too far or institutionalized in the wrong way, could be an obstacle to effective expert advice and knowledge-based policy-making. Following this line of reasoning, increased decision quality and the democratization of expertise are no longer two sides of the same coin. Rather, the Commission admits, the twin concerns of "legitimacy and efficiency" may entail some potential "trade-offs" (European Commission, 2001b), and the need to create a balance between "adequate input" and "swift decision-making" (European Commission 2002b).

One expression of this non-harmonizing approach is the Commission's apparent need to put some limits on the transparency and democratization agenda in order to maintain knowledge-based and swift decisionmaking. Concerns of this kind are reflected in general remarks on expertise and what a sound, "balanced" approach to expert advice would look like; for example,

\footnotetext{
7 A cynic would not have to doubt the real engagement and sincerity of the 2007 expert group report authors, several of them prominent academics in their field. What they would argue, rightfully or not, is that the Commission uses this report strategically to give its "smooth talk" on the use and role of expertise some apparent grounding.
} 
with regard to "openness": “(...) there are circumstances when too much openness could be detrimental to the quality of advice, or may damage the legitimate interest of those concerned with the process. The level of openness should be tailored in proportion to the task at hand" (European Commission, 2002a). Discussions relating to the potential limits of "democratizing expertise" also come up directly in relation to the expert group system and the guidelines for this system. There is, for example, a concern that the desire for greater participation may lead to overcrowding in groups which will compromise their effectiveness and problem-solving capacities. There is, therefore, a need to "ensure that an excessive multiplication of expert groups is avoided", and that "the number of members in the group" remains "limited in order to guarantee the effective operation of the group and ensure the quality of expertise" (European Commission, 2005).

Finally, there are passages where the Commission suggests that critics' demands for democratization are normatively and institutionally misplaced, or at least potentially in tension with sound intuition about how knowledge should be utilized and the nature of democracy in the EU. An example of this is the Commission's concern that the idea of "democratizing expertise" is understood as an idea of "majority voting in science", that expert advice is dismissed and considered illegitimate if it is not in accordance with majority views. The Commission is also uneasy with how its use of expertise has been made a key target of critics of the EU's democratic deficit when the main challenges to the deficit arguably lie elsewhere. There may be "no contradiction between wide consultation and the concept of representative democracy. However, it goes without saying that, first and foremost, the decision-making process in the EU is legitimized by the elected representatives of the European people" (European Commission, 2002b). The contention here is that proponents of the democratization of the expertise approach tend to confuse the democratic deficit debate, fixating on the Commission and ignoring the larger institutional context and the fundamental role, not least, of the European Parliament and the Council for developing EU democracy and problematically replacing the normative ideal of "representative democracy" with that of "consultation" democracy.

Again, one may or may not share these worries and be more or less convinced by the Commission's tradeoff arguments, and as they are discussed symbiotically with a harmonization discourse, the idea of a hard choice between democratization and instrumental knowledge utilization is articulated with considerable ambivalence. There is no doubt, however, that the Commission problematizes the democracy, accountability and transparency demands of critics substantively. There are few traces of cosmetic or hypocritical responses to critics' concerns on this point; on the contrary, Commission critics, their agenda and parameters are challenged and critically engaged with in a way that fits badly with a cynical reading.

\section{3. $\mathrm{CH} / \mathrm{DH} 3 \mathrm{a}$ and $\mathrm{CH} / \mathrm{DH} 3 \mathrm{~b}$ : The Commission Tends to Avoid the Unpleasant Topics of Internal Democratic Deficiencies and Politicized Uses of Expertise within Its Own Ranks}

The Commission documents provide, however, no descriptions, analyses or assessments of the Commission's current practices of expert organization and advice from a democratic perspective. The Commission subscribes generally to ideals of democracy and of democratizing expert bodies and procedures despite its concern that "too much" of this or using it "in the wrong way" could compromise problem-solving merits. Several of the proposed regulations of the Commission's expert arrangements, moreover, indirectly recognize critics' democratic concerns. As we have argued, all these findings give leverage to a deliberative reading of the documents. Scrutiny of the Commission's ongoing internal practices from a democratic point of view could, however, have brought attention to democratic deficiencies, in the eye of critics, but also in the eye of the Commission itself. When the documents avoid this issue, this is accordance with cynical expectations of avoiding unpleasant topics.

The topic of politicized use of expertise within the Commission's own ranks is also avoided, exactly as cynics would anticipate. Once more, the Commission recognizes the problem in general terms. The problem of selective and opportunistic use of expertise is discussed and problematic implications are highlighted, varying from reduced public "trust" in expert arrangements and a decrease in "the credibility of science" to lower quality policy outcomes (European Commission, $2001 b)$. And, once more, the problem is recognized indirectly through the introduction of concrete regulatory prescriptions. A focused discussion and assessment of the Commission's non-instrumental knowledge utilization practices as a characteristic of this organization and something concretely and ongoing, is however missing from the documents. Such practices have been identified in research on the Commission's use of expertise, and they are most likely well known among Commission officials themselves. When they are not recognized and addressed, this is in accordance with the cynical expectation of avoiding delicate and difficult issues.

\section{Conclusions and Precautions}

Overall, we can conclude that cynical expectations are in accordance with a dominant interpretative scheme among Commission critics, and supported by a branch of organizational theory, but only partially supported 
by our data. Firstly, even if the Commission's support for instrumental knowledge utilization and firm dismissal of the strategic uses of expertise is compatible with a cynical reading, the introduction of concrete regulatory initiatives by the Commission to ensure neutrality and problem-solving credentials in its expert advice practices gives leverage to a deliberative approach. Secondly, the Commission problematizes critics' democratization demands and addresses possible contradictions between these demands and the concern for high quality decisions and good policy outcomes. These findings indicate deliberation and counter the expectations of the cynical approach. Cynical hypotheses about the Commission's approach to unpleasant topics are, however, strengthened.

The partial confirmation of deliberative hypotheses is not totally unsurprising and supports existing studies of the Commission that already challenge the cynical perspective (Cini, 2014; Cram, 1994; Heritier, 1999; Kassim, 2008; Pollack, 2003; Wille, 2013). Our study also adds to existing scholarship on deliberation in EU policy and decision-making (Eriksen, 2009, 2014; Eriksen \& Fossum, 2012; Joerges, 2001; Sjursen, 2011; Stie, 2013).

A promising branch of EU deliberation studies have developed the quality of deliberation indicators, which makes it possible to measure the more detailed levels and characteristics of deliberation (Bächtiger, Niemeyer, Neblo, Steenbergen, \& Steiner, 2010; see also Neblo, 2007). We did not apply such indicator sets in our study because our aim was to compare the relative merits of a cynical and a deliberative approach, and high scores on deliberative indicators often lend themselves equally well to both cynical and deliberative readings, i.e. it is notoriously hard to say whether "good arguments" in public communication reflect "a commitment to public reasoning" (Cohen, 1997), or a cynical attempt to look like a "good deliberator".

Furthermore, what we have assessed in this article are particular branches and interpretations of organizational and deliberative theory and a limited set of hypotheses. Our attention has, moreover, been on the Commission's communications about its expertise policies and practices and not on actual implementation. Obviously, more studies are needed to get a fuller picture.

Finally, we believe our findings raise significant normative questions. One is whether critics are right in dismissing strategic practices of knowledge utilization outright, or whether a normative case can be made for such practices that are no doubt ongoing in the Commission and other executive organizations. Another is whether the Commission is right to keep so quiet about it.

\section{Acknowledgements}

Drafts of this paper have been presented at the Oslo network for research on science, expertise and policy advice Winter 2014/2015 workshop, at the Nytt Norsk
Tidsskrift editorial seminar and in the Quality of Government (QoG) institute seminar series, University of Gothenburg. We thank participants on these occasions and three anonymous reviewers for useful comments.

\section{Conflict of Interests}

The authors declare no conflict of interests.

\section{References}

Aberbach, J., Putnam, R., \& Rockman B. (1981). Bureaucrats and politicians in Western Democracies. Cambridge: Harvard University Press.

Alter-EU. (2013). A year of broken promises: Big business still put in charge of EU Expert Groups despite commitment to reform. Alter-EU Europe's campaign for lobbying transparency. Retrieved from http://www.alter-

eu.org/sites/default/files/documents/Broken_Prom ises_web.pdf

Alter-EU. (2014). Draft amendment for Expert Groups budget freeze. Retrieved from http://www.altereu.org/documents/2014/09-5

Bächtiger, A., Niemeyer, S., Neblo, M., Steenbergen, M. R., \& Steiner, J. (2010). Disentangling diversity in deliberative democracy: Competing theories, their blind spots and complementarities. Journal of Political Philosophy, 18(1), 32-63.

Besson S. \& Martí, J. L. (2006). Deliberative democracy and its discontents. Aldershot: Ashgate.

Böhling, K. (2014). Sidelined member states: Commission-learning from experts in the face of comitology. Journal of European Integration, 36(2), 117-134.

Bohman, J. \& Rehg, W. (1997). Deliberative democracy: Essays on reason and politics. Cambridge: The MIT Press.

Boswell, C. (2008a). The political functions of expert knowledge and legitimation in European Union immigration policy. Journal of European Public Policy, 15(4), 477-488.

Boswell, C. (2008b). Evasion, reinterpretation and decoupling: European Commission responses to the "external dimension" of immigration and asylum. West European Politics, 31(3), 491-512.

Brunsson, N. (2002). The organization of hypocrisy: Talk, decisions and actions in organizations. Copenhagen: Abstrakt \& Liber.

Chambers, S. (2003). Deliberative democratic theory. Annual Review of Political Science, 6, 307-326.

Chambers, S. (2004). Behind closed doors: Publicity, secrecy, and the quality of deliberation. The Journal of Political Philosophy, 12(4), 389-410.

Christiano, T. (2012). Rational deliberation among experts and citizens. In J. Parkinson \& J. Mansbridge (Eds.), Deliberative systems: Deliberative democracy at the large scale (1st ed., pp. 27-51). Cambridge: 
Cambridge University Press.

Christiansen, T., \& Kricher, E. (2000). Europe in change: Committee governance in the European Union. Manchester: Manchester University Press.

Christiansen, T., \& Larsson, T. (2007). The role of committees in the policy-process of the European Union: Legislation, implementation and deliberation. Cheltenham: Edward Elgar Publishing.

Cini, M. (2014). The European Commission after the reform. In J. Magone (Ed.), Routledge handbook of European politics. London: Routledge.

Cohen, J. (1997). Deliberation and democratic legitimacy. In J. Bohman \& W. Rehg (Eds.), Deliberative democracy: Essays on reason and politics (1st ed., pp. 67-91). Cambridge: MIT Press.

Cram, L. (1994). The European Commission as a multi-organization: Social policy and IT Policy in the EU. Journal of European Public Policy, 1(2), 195-217.

Dehousse, R. (2011). The community method: Obstinate or obsolete? Palgrave Macmillan: London.

Dehousse, R., \& Thompson, A. (2013). The Commission in the EU institutional system: A citadel under siege. In Hussein, K. Peterson, J. Bauer, M. W. Connolly, S. Dehousse, R. Hooge, L., \& Thompson, A., The European Commission of the 21st century. Oxford: Oxford University Press.

DiMaggio, P. J., \& Powell, W. W. (1983). The iron cage revisited: Institutional isomorphism and collective rationality in organizational fields. American Sociological Review, 48(2), 147-160.

Egeberg, M., Schaefer, G., \& Trondal, J. (2003). The Many faces of EU Committee governance. West European Politics, 26(3), 19-40.

Egeberg, M. (2004). An organizational approach to European integration: Outline of a complementary perspective. European Journal of Political Research, 43(2), 199-219.

Eising, R. (2007). The access of business interests to EU institutions: Towards elite pluralism. Journal of European Public Policy, 14(3), 384-403.

Ellinas, A., \& Suleiman E. (2012). The European Commission and bureaucratic autonomy. Europe's custodians. New York: Cambridge University Press.

Eriksen, E. O. (2009). The Unfinished democratization of Europe. Oxford: Oxford University Press.

Eriksen, E. O. (2014). The normativity of the European Union. New York: Palgrave Macmillian.

Eriksen, E. O., \& Fossum, J. E. (2012). Rethinking democracy and the European Union. London: Routledge.

European Commission. (2000). Commission Working Document: Science, Society and the Citizen in Europe. SEC (2000)1973, 14 November 2000. Brussels, Belgium: EU Commission.

European Commission. (2001a). European Governance: A White Paper. COM(2001) 428 final, 25 July 2001. Brussels, Belgium: EU Commission.

European Commission. (2001b). Report of the Working
Group "Democratizing Expertise and Establishing Scientific Reference Systems", final version, 2 July 2001. Brussels, Belgium: EU Commission.

European Commission. (2002a). Communication from the Commission on the Collection and Use of Expertise by the Commission: Principles and Guidelines"Improving the Knowledge Base for Better Policies", COM (2002) 713 final, 11 December 2002. Brussels, Belgium: EU Commission.

European Commission. (2002b). Communication from the Commission: Towards a Reinforced Culture of Consultation and Dialogue-General Principles and Minimum Standards for Consultation of Interested Parties by the Commission, COM (2002) 704 final, 11 December 2002. Brussels, Belgium: EU Commission.

European Commission. (2005). Communication from the President to the Commission in Agreement with the Vice-President Responsible for Administrative Affairs and the Member of the Commission Responsible for Financial Programming and BudgetFramework for Commission Expert Groups: Horizontal Rules and Public Register. C(2005)2817, 27 July 2005. Brussels, Belgium: EU Commission.

European Commission. (2007). Taking European Knowledge Society Seriously-Report of the Expert Group on Science and Governance to the Science, Economy and Society Directorate, DirectorateGeneral for Research, European Commission. Luxembourg: European Communities.

European Commission. (2010a). Communication from the President to the Commission: Framework for Commission Expert Groups: Horizontal Rules and Public Register. C(2010) 7649 final, 11 November 2010. Brussels, Belgium: EU Commission.

European Commission. (2010b). Commission Staff Working Document Accompanying Document to the Communication from the President to the Commission - Framework for Commission Expert Groups: Horizontal Rules and Public Register. SEC(2010) 1360 final, 10 November 2010. Brussels, Belgium.

European Commission. (2012). State of Play Concerning the Condition set by the European Parliament to Lift the Reserve in the 2012 Budget With Regards to Groups of Experts (EUR 2 million), September 2012. Retrieved from http://www.alter-eu.org/sites/de fault/files/documents/State\%20of\%20play\%20_\%2 06\%20SEPTEMBER\%202012\%20_\%20CLEAN.pdf

European Commission. (2013). Informal Dialogue on Expert Groups Initiatives Taken by Commission. State of Play-February 2013. Retrieved from http: //www.alter-eu.org/sites/default/files/documents/ COMMISSION_STATE\%20OF\%20PLAY\%20_\%20FE BRUARY\%202013\%20_\%20FINAL.pdf

Featherstone, K. (1994). Jean Monnet and the "democratic deficit" in the European Union. Journal of 
Common Market Studies, 32(2), 149-170.

Fischer, R. (2008). European governance still technocratic? New modes of governance for food safety regulation in the European Union. European Integration Online Papers, 12(66), 1-22. Retrieved from http://eiop.or.at/eiop/index.php/eiop/article/view/ 2008_006a/83

Gallie, W. B. (1956). Essentially contested concepts. Proceedings of the Aristotelian Society, 56, 167-198.

Gornitzka, Å., \& Sverdrup, U. (2008). Who consults? The configuration of Expert Groups in the European Union. West European Politics, 31(4), 725-750.

Gornitzka, Å., \& Sverdrup, U. (2010). Access of experts: Information and EU Decision-Making. West European Politics, 34(1), 48-70.

Green-Cowles, M. (1995). Setting the agenda for a new Europe: The ERT and the EC 1992. Journal of Common Market Studies, 33(4), 501-526.

Groenleer, M. (2009). The autonomy of European Union agencies: A comparative study of institutional development. Delft: Eburon.

Geuss, R. (2001). History and Illusions in Politics. Cambridge: Cambridge University Press.

Gutmann, A., \& Thomposon D. (2004). Why deliberative democracy? Princeton: Princeton University Press.

Haas, (2004). When does power listen to truth? A constructivist approach to the policy process. Journal of European Public Policy, 11(4), 569-592.

Habermas, J. (2012). The crisis of the European Union: A response. Cambridge: Polity Press.

Harcourt, A., \& Radaelli, C. (1999). Limits to EU technocratic regulation? European Journal of Political Research, 35(1), 107-122.

Herbst, S. (2003). Political authority in a mediated age. Theory and Society, 32, 481-503.

Héritier, A. (1999). Policy-making and diversity in Europe. Escaping from deadlock. Cambridge: Cambridge University Press.

Hsieh, H.-F., \& Shannon E. S. (2005). The approaches to qualitative content analysis. Qualitative Health Research, 15(9), 1277-1288.

Joerges, C. (2001). Deliberative supranationalism: A defence. European Integration Online Paper, 5(8). Retrieved from http://eiop.or.at/eiop/texte/2001008a.htm

Joerges, C., \& Neyer, J. (1997). From intergovernmental bargaining to deliberative political processes: The constitutionalism of comitology. European Law Journal, 3, 273-299.

Kassim, H. (2008). "Mission impossible", but mission accomplished: The Kinnock reforms and the European Commission. Journal of European Public Policy, 15(5), 648-668.

Larsson, T. (2003). Pre-cooking in the European Union: The world of Expert Groups. Stockholm: Ministry of Finance.
Majone, G. (1996) Regulating Europe. London: Routledge.

Majone, G. (2014). Rethinking the Union of Europe post-crisis. Has integration gone too far? Cambridge: Cambridge University Press.

Mansbridge J., \& Parkinson J. (2012). Deliberative systems: Deliberative democracy at the large scale. Cambridge: Cambridge University Press.

Martí, J. L. (2006). The epistemic conception of deliberative democracy defended. In S. Besson \& J. L. Martí (Eds.), Deliberative democracy and its discontents (pp. 27-56). Aldershot: Ashgate.

Mayring, P. (2000). Qualitative content analysis. Qualitative Social Research, 1(2). Retrieved from http://www.qualitativeresearch.net/index.php/fqs/ article/view/1089/2385\%3E

Metz, J. (2013). Expert Groups in the European Union: A suis generis phenomenon? Policy and Society, 32(3), 267-278.

Meyer, J. W., \& Rowan, B. (1977). Institutionalized organizations: Formal structure as myth and ceremony. American Journal of Sociology, 83(2), 340-363.

Meyer, J. W., \& Scott, W. R. (1983). Organizational environments: Ritual and rationality. Sage: London.

Moodie, J. (2011). The European Commission and European Technology platforms: Managing knowledge and expertise in European research and technology policy (Doctoral dissertation). Retrieved from https://theses.ncl.ac.uk/dspace/handle/10443/1820

Neblo, M. A. (2007). Family disputes: Diversity in defining and measuring deliberation. Swiss Political Science Review, 13(4), 527-557.

Offe, C. (2014). Europe entrapped. Cambridge: Polity.

Pedler, R. H., \& Schaefer, G. F. (1996). Shaping European law and policy: The role of committees and comitology in the political process. Maastricht: European Institute of Public Administration.

Pollack, M. (2003). The engines of European integration: Delegation, agency and agenda-setting in the EU. Oxford: Oxford University Press.

Presson, T. (2007). Accountability and expertise in the European Union. Presented at the CONNEX-RG2 Workshop on "Delegation and Mechanisms of ACcountability in the EU". Uppsala, Uppsala University, 8-9 March 2007.

Radaelli, C. (1995). The role of knowledge in the policy process. Journal of European Public Policy, 2(2), 159-183.

Radaelli, C. (1999). Technocracy in the European Union. London \& New York: Longman.

Radaelli, C. (2009). Measuring policy learning across Europe: Regulatory impact assessment in comparative perspective. Journal of European Public Policy, 16(8), 1145-1164.

Rhinard, M. (2002). The democratic legitimacy of the European Union Committee system. Governance: An International Journal of Policy, Administration 
and Institutions, 15(2), 185-210.

Rimkute, D., \& Haverland, M. (2014). How does the European Commission use scientific expertise? Results from a survey of scientific members of the Commission's Expert Committees. Comparative European Politics. Retrieved from http://www.palgravejournals.com/cep/journal/vaop/ncurrent/full/ cep201332a.html

Ross, G. (1995). Jacques Delors and European integration. Cambridge: Polity Press.

Sandholtz, W., \& Zysman, J. (1989). Recasting the European bargain. World Politics, 42(1), 95-128.

Schaefer, G. (2002). Governance by committee: The role of committees in European policy-making and policy implementation. Luxembourg: European Communities.

Scharpf, F. (1999). Governing in Europe: Effective and democratic? Oxford University Press

Schrefler, L. (2010). The usage of scientific knowledge by independent regulatory agencies. Governance: An International Journal of Policy, Administration and Institutions, 23(2), 309-330.

Schrefler, L. (2013). Economic knowledge in regulation: The use of expertise by independent agencies. Colchester: ECPR Press.

Shore, C. (2000). Building Europe: The cultural politics of European integration. London: Routledge.

Scott, R. W. (2004). Reflections on a half-century of organizational sociology. Annual Review of Sociology, 30, 1-21.

Sjursen, H. (2011). Not so intergovernmental after all? On democracy and integration in European Foreign and Security Policy. Journal of European Public Policy, 18(8), 1078-1095.
Stie, A. E. (2013). Democratic decision-making in the EU: Technocracy in disguise? London: Routledge.

Thompson, D. (2008). Deliberative democratic theory and empirical political science. Annual Review of Political Science, 11, 497-520.

Trondal, J. (2001). Is there any social constructivistinstitutionalist divide? Unpacking social mechanisms affecting representational roles among EU decision-makers. Journal of European Public Policy, 8(1), 1-23.

Vassalos, Y. (2013).European Commission's Expert Groups: Damocles' sword over democracy. Juridikum, 1.

Vos, E. (1997). The rise of committees. European Law Journal, 3(3), 210-229.

Wallace, W., \& Smith, J. (1995). Democracy or technocracy? European integration and the problem of popular consent. West European Politics, 18(3), 137-157.

Weiss, C. (1977). Research for policy's sake: The enlightenment function of social research. Policy Analysis, 3(4), 531-545.

Weiss, C. (1979). The many meanings of research utilization. Public Administration Review, 39(5), 426431.

Weiss, C. (1986). Research and policy-making: A limited partnership. In F. Heller (Ed.), The use and abuse of social science (pp. 214-235). London: Sage.

Weiss, C. (1999). The interface between evaluation and public policy. Evaluation, 5(4), 468-486.

Wille, A. (2013). The normalization of the European Commission: Politics and bureaucracy in the EU executive. Oxford: Oxford University Press.

\section{About the Authors}

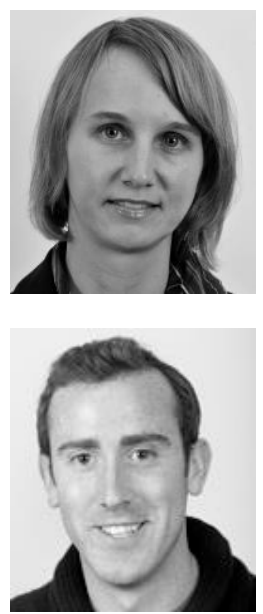

\section{Dr. Cathrine Holst}

Cathrine Holst is a Senior Researcher at ARENA-Centre for European Studies, University of Oslo where she coordinates the project Why not epistocracy? (EPISTO). Holst's research interests are democratic theory, political epistemology, expertise politics, European studies, and gender studies. Recent publications are "Why democracy? On the relationship between gender democracy and gender equality in the EU", and "Jürgen Habermas on public reason and religion: Do religious citizen suffer an asymmetrical cognitive burden, and should they be compensated?" (with Anders Molander).

\section{Dr. John. R. Moodie}

John. R. Moodie is a post-doctoral research fellow working on the EPISTO project at ARENA-Centre for European Studies, University of Oslo. His research interests include technocratic theory and the role, function and legitimacy of knowledge and expertise-based bodies in EU policy-making, particularly in the area of European research and technology policy. He obtained his PhD in Political Science from the University of Newcastle upon Tyne in 2011 and has an MA in Politics (Research) from the University of Newcastle upon Tyne. 